University of Northern lowa

UNI ScholarWorks

Faculty Publications

Faculty Work

1987

\title{
The Life and Unusual Ideas of Adelbert Ames, Jr.
}

Roy R. Behrens

University of Northern lowa

Let us know how access to this document benefits you

Copyright (C)1987 The MIT Press

Follow this and additional works at: https://scholarworks.uni.edu/art_facpub

Part of the Art and Design Commons

\section{Recommended Citation}

Behrens, Roy R., "The Life and Unusual Ideas of Adelbert Ames, Jr." (1987). Faculty Publications. 5. https://scholarworks.uni.edu/art_facpub/5

This Article is brought to you for free and open access by the Faculty Work at UNI ScholarWorks. It has been accepted for inclusion in Faculty Publications by an authorized administrator of UNI ScholarWorks. For more information, please contact scholarworks@uni.edu. 


\title{
The Life and Unusual Ideas of Adelbert Ames, Jr.
}

\author{
Roy R. Behrens
}

\begin{abstract}
This paper is a summary of the life and major achievements of Adelbert Ames, Jr., an American ophthalmologist and perceptual psychologist, who had initially wanted to be a visual artist. He is most widely remembered today as the inventor of the Ames Demonstrations in Perception, the most famous of which consists of a distorted room in which people seem to shrink as they walk from one corner to another. This essay discusses the relationship of the Ames Demonstrations to anamorphic visual art, and it documents various comments by perceptual psychologists and artists who were directly acquainted with Ames.
\end{abstract}
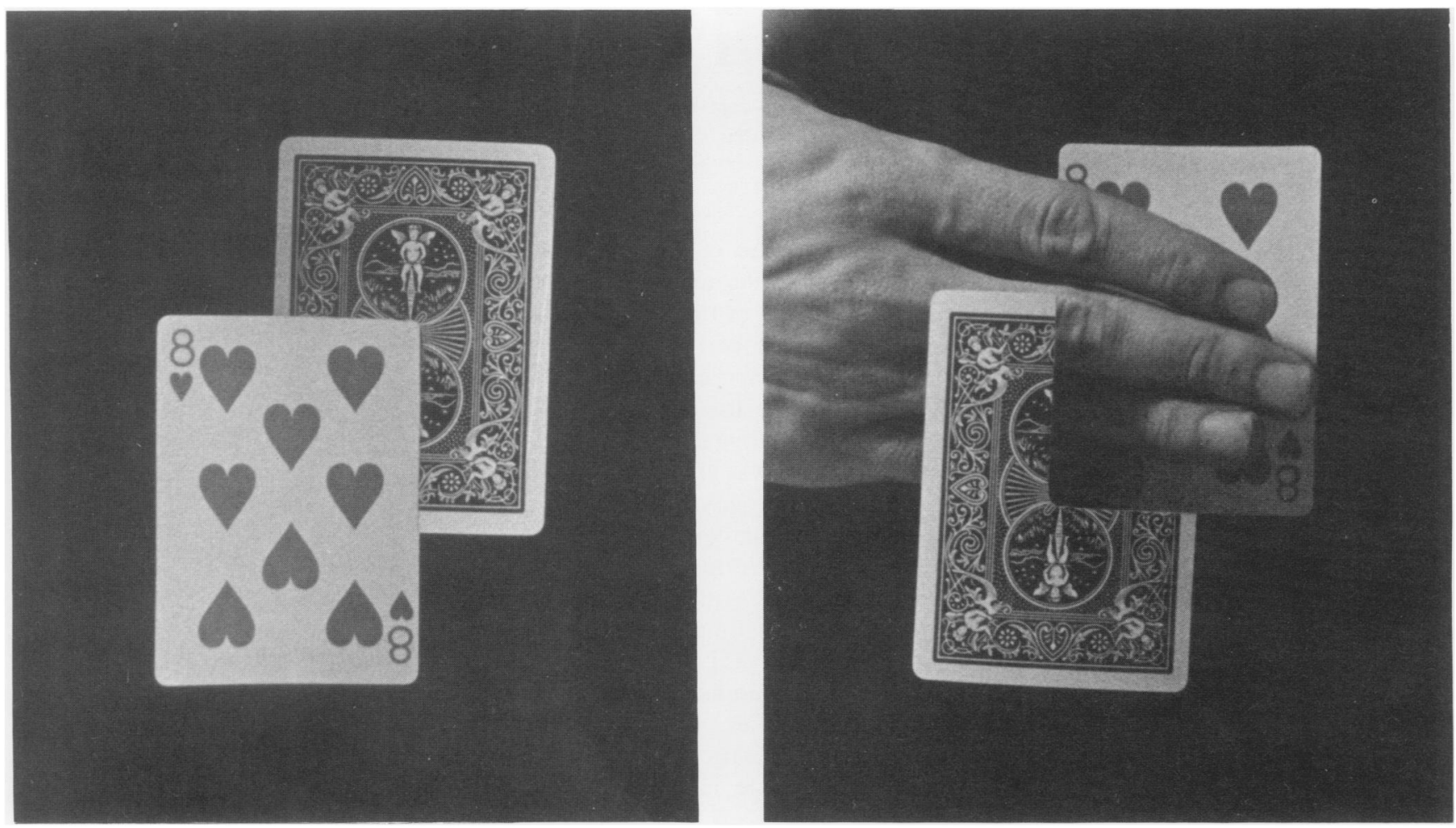

Fig. 1. In the Overlay Demonstration (this is a reconstruction of only one part of the original version), Ames removed a corner section of a playing card so that the card more distant from the viewer (the eight of hearts) appears to be less distant.

\section{INTRODUCTION}

Adelbert Ames, Jr. (1880-1955) was an American ophthalmologist and perceptual psychologist who had initially wanted to be a visual artist [1].

As an ophthalmologist, he is credited with the diagnosis of aniseikonia, a malformation of the eyes in which the right and left retinal images are so distinctively varied in size that they cannot readily be fused by the brain.

As a perceptual psychologist, he is

Roy R. Behrens (artist, writer, teacher), Ballast Quarterly Review, Art Academy of Cincinnati, Eden Park, Cincinnati, OH 45202, U.S.A.

Received 27 May 1986 more widely remembered today as the inventor of the Ames Demonstrations in Perception, a series of visual illusions, the most famous of which consists of a fullsized distorted room which appears to be normal from one point of view, but in which people seem to shrink as they walk from one corner to another [2].

For about 15 years, I have been actively interested in the life and unusual ideas of Ames. I am familiar with his published writings, and I have read most of the papers and books in which his work has been assessed. Over the years, in collaboration with a number of my students and colleagues, I have reconstructed some of his demonstrations. As an artist, I am especially interested in the surprising resemblance between some of the Ames Demonstrations and certain types of visual art, both historical and contemporary. This paper is a brief review of the life and the major achievements of Ames.

\section{HIS INTEREST IN THE VISUAL ARTS}

Ames was born on 19 August 1880, in Lowell, Massachusetts. His maternal grandfather was General Benjamin Butler, Governor of Massachusetts and an unsuccessful candidate for President in 1884 [3]. His paternal grandfather was Captain Jesse Ames, proprietor of the Ames Mill in Northfield, Minnesota [4]. 

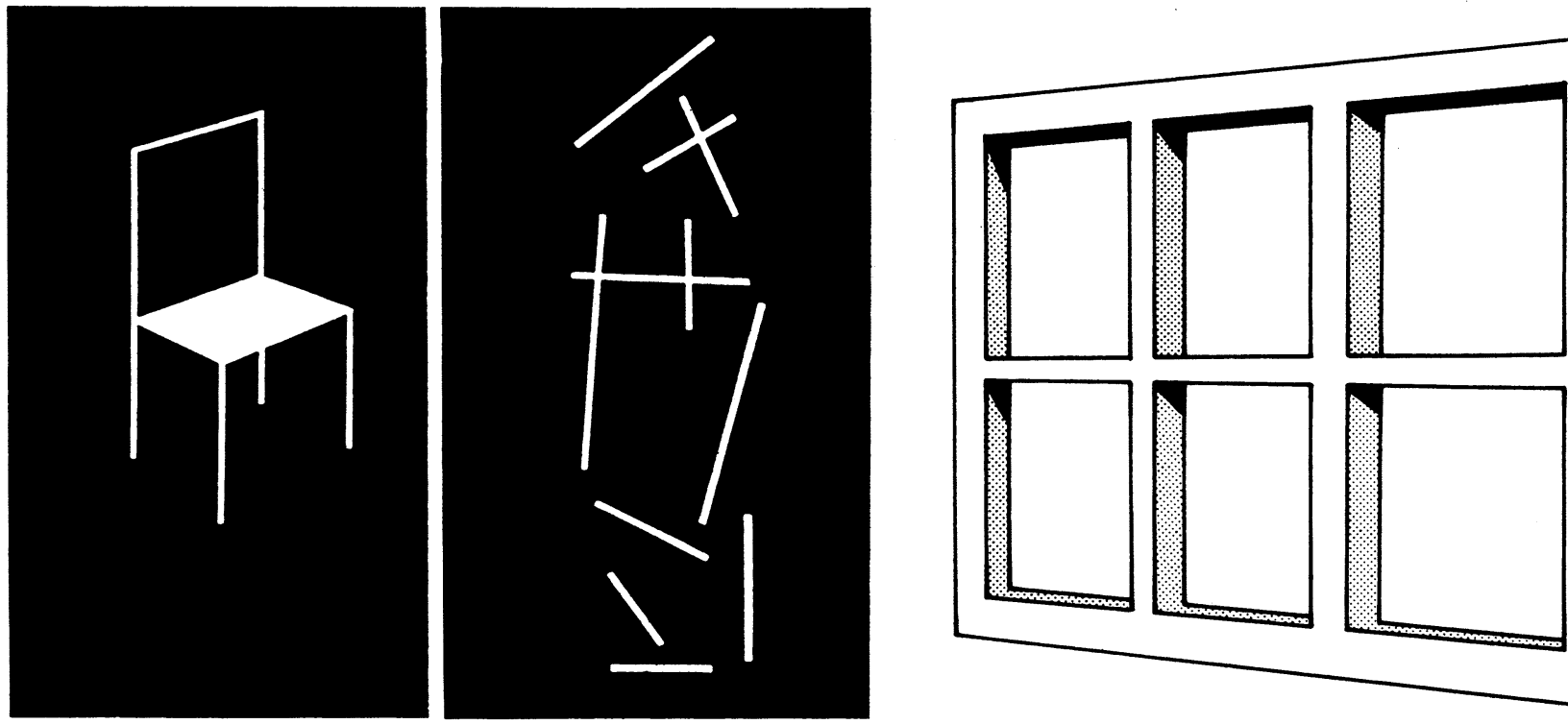

Fig. 2. In the Chair Demonstration, an object that looks like a chair is observed through a peephole (a). However, when viewed from another position, what appeared to be a chair is revealed to be merely an assembly of odd and nonsensical shapes (b).

Fig. 3. In the Rotating Trapezoid Demonstration, a cutout of a trapezoid is painted so as to appear to be a rectangular window in perspective. When rotated on a motorized shaft, the trapezoid appears to be a rectangular window that is swaying back and forth.

His father was General Adelbert Ames, U.S. Senator and Governor of Mississippi [5].

Ames was educated at Harvard University, from which he was granted a Bachelor of Arts degree in 1903 and a Bachelor of Law in 1906. For 4 years, he worked as a lawyer in Boston [6].

In 1910, Ames abandoned the practice of law because he was "disillusioned in the law and disappointed in love" [7]. $\mathrm{He}$ may have studied painting in Boston. For part of 1912 at least, he spent a large amount of time in North Easton, Massachusetts (20 miles south of Boston), where he tried to learn to paint with his older sister, Blanche Ames Ames, a botanical illustrator and the wife of the Harvard botanist Oakes Ames [8]. Another sister, Jesse Ames, was also a painter, described by one observer as "an inspired amateur of extraordinary power" [9].

In his own words, Ames' goal as an artist was "to make exact color reproductions of scenes" [10]. To this end, he and his sister Blanche devised one of the first color notation systems, which involved the mixing and categorizing of more than 3,300 discernibly different color variations, consisting of 27 hues, 15 gradations in value, and 10 steps in intensity (or chroma) for each hue [11]. By comparison, the Munsell Color System, published as an atlas in 1915, contains only 1,200 color variations [12].

When painting outdoor landscapes, Ames and his sister would hold in the air the color sample that seemed to be most similar to the color of each section of the outdoor scene, as viewed from a constant position. The number of the colored card was recorded on the canvas and, after numerous features of the landscape had been matched with corresponding color swatches, the appropriate paint would be filled in [13]. They also used these cards indoors while painting still lifes [14].

In 1914, Ames was granted a research fellowship in physiological optics at Clark University in Worcester, Massachusetts. During World War I, he served in the U.S. Signal Corps as a captain and aerial observer, his tour of duty lasting from 1917 to 1919 [15].

In 1919, Ames resumed his research in physiological optics, which he now conducted not at Clark University but at Dartmouth College in Hanover, New Hampshire. Two years later, Dartmouth appointed him a research professor in optics, a position he retained until he was 66 years old [16].

\section{FROM ART TO PHYSIOLOGICAL OPTICS}

When Ames first became engaged in research, he may not have had the intention of abandoning painting, although as it happened he never took it up again [17]. By one account, he developed an interest in physiological optics "as a result of his consideration of the artist's need to see objectively and the relationship of that need to the underlying properties of vision" [18].

As early as 1913, when Ames was supposedly learning to paint, he was already working with J.W. Baird, a Clark University psychologist, in the hope of defining the attributes of the pictures that form on the back of the eye. Before Ames went off to war, they attempted unsuccessfully to measure the sensitivity to color of different regions of the retina [19].

In 1919, when Ames returned to his research, he worked with a Dartmouth physicist, Charles A. Proctor. Together, assisted by Blanche Ames, they investigated the characteristics of retinal images with the aim of inventing a 'binocular camera' which would simulate not merely a retinal image but what Ames referred to as a 'mental visual image', the superimposition of two retinal images, which he assumed was in the brain. The early results of these efforts (including a 'binocular photograph') were published in 1923 in a paper entitled "Vision and the Technique of Art" [20].

At that time, it was Ames' belief that it should be the goal of an artist to depict, as accurately as possible, the way a scene would appear to one's eyes if one's gaze were affixed to a stationary focal point [21].

In an ideal painting, according to Ames, only those objects that happen to fall within the center of interest (which need not be the center of the painting) would be clearly focused and shown in detail. All other parts of the painting would be blurred, more or less, including those that are horizontally and vertically peripheral and those that are nearer or farther away. Like a mental visual image (two retinal images superimposed), such an artwork would be characterized by barrel distortion (because of the curve of the retinal plane), chromatic aberrations (because of the differing wave lengths) 


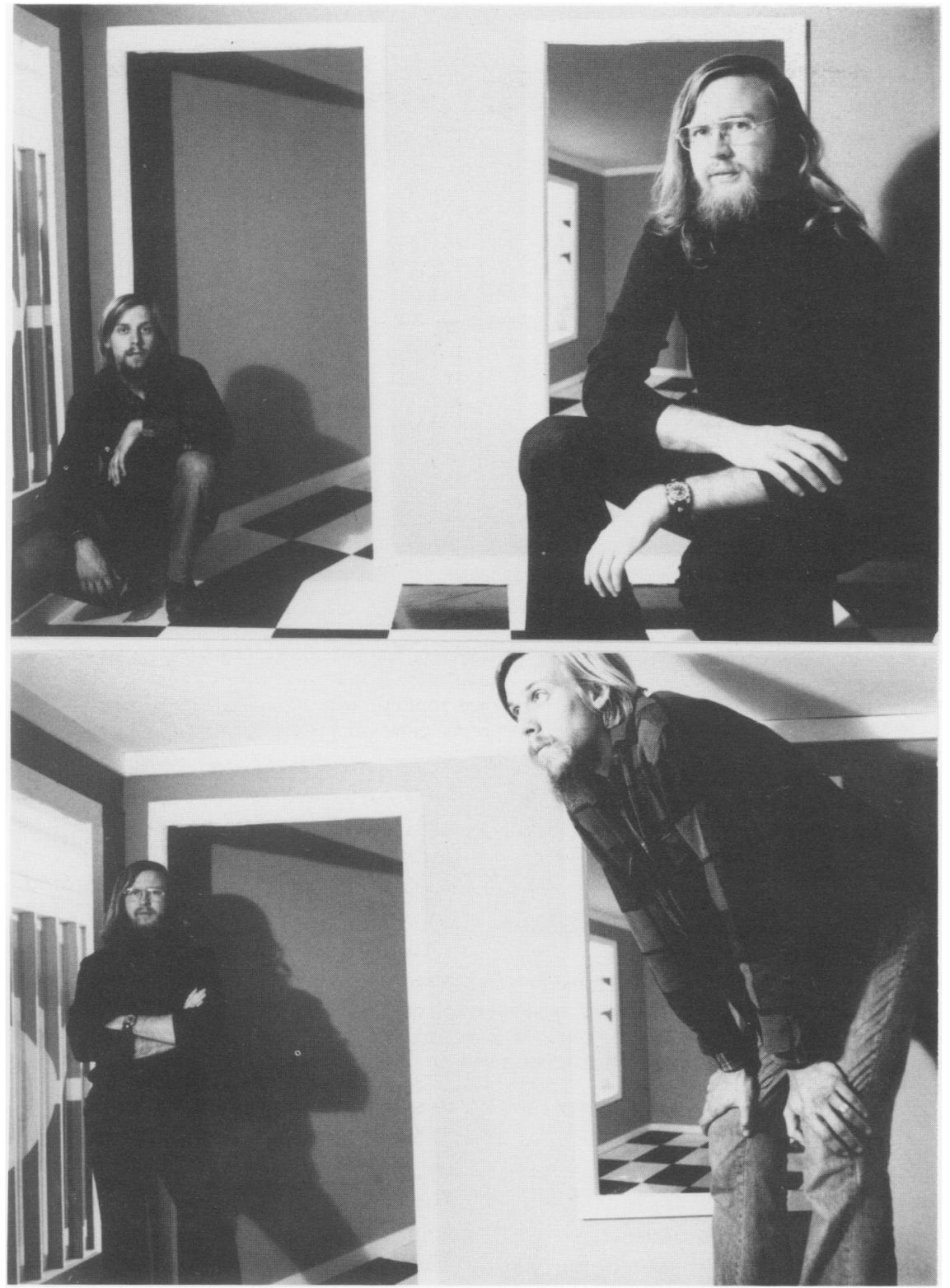

Fig. 4. In the Distorted Room Demonstration, a crooked room appears to be normal from one point of view. When objects and people are placed in the room, they seem dramatically altered in size.

and so on. Ames found it of interest and value that a binocular photograph had some of these characteristics [22].

It is essential to realize that Ames' binocular photographs were not stereoscopic (three-dimensional) photographs. Ames' binocular camera made use of two parallel lenses (positioned as if they were a pair of human eyes), but it produced only one photograph in which two different exposures were superimposed. Contrarily, while two parallel lenses are also employed in a stereoscopic camera, two separate photographs are produced [23]. In viewing a binocular photograph, both eyes concurrently observe the same single photograph. When one views a pair of stereoscopic photographs, one of the photographs is observed by the right eye, while the other is observed by the left. The brain then combines the two, and the figure appears to pop out from the ground [24].

Ames' experiments with binocular photographs (as rough simulations of ideal paintings) led him to investigate the characteristics of stereoscopic photographs. It was this research that led to the discovery of aniseikonia, a malfunction of the eyes, which led him in turn to the development of the Ames Demonstrations in Perception [25].

\section{ANISEIKONIA}

Aniseikonia is an unusual visual defect in which the two retinal images are so dramatically varied in size and shape that they cannot readily be fused by the brain [26]. A person who is aniseikonic tends to make errors in judging the size, shape and location of objects. Initially, deformation of the eyes was not suspected as the cause, since the symptoms of aniseikonia (nausea, headache, uneasiness) were commonly thought to be signs of neurosis and other emotional disturbances [27].

Ames discovered aniseikonia in 1926. Throughout the following decade, he examined the eyes of hundreds of patients "from all over the country and also from abroad" who were thought to be aniseikonic [28]. He published a series of technical papers in journals of optics and ophthalmology [29], and he secured the patents for approximately 15 instruments intended for use in the diagnostic measurement and treatment of aniseikonia [30].

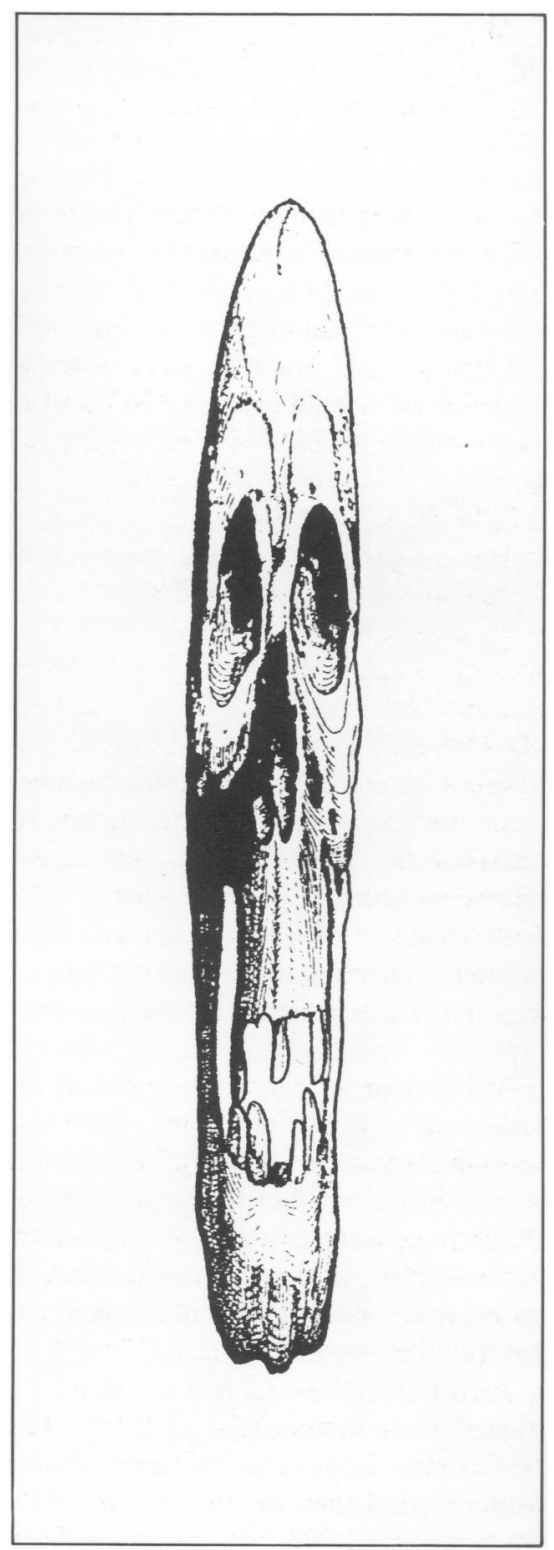

Fig. 5. An historical example of anamorphosis, an engraving of a skull, originally published in a book on perspective by Lucas Brunn, circa 1615. The picture appears to be normal when viewed obliquely from the top. 
In 1936, the Dartmouth Eye Institute was established, with Ames as Director of Research. The institute was funded by John D. Rockefeller, Sr., the Rockefeller Foundation, the American Optical Company and several individual benefactors [31]. According to one source, a member of the Rockefeller family who was aniseikonic was successfully treated by Ames [32]. By the time the institute was closed in 1949, the staff had grown to include 30 medical and scientific workers [33].

It is evidence of Ames' achievement as an ophthalmologist that he was the second recipient of the Edgar D. Tillyer Medal, the highest award of the Optical Society of America. This honor, received 3 months before his death, was for "distinguished work in the field of vision, including (but not limited to) the optics, physiology, anatomy, or psychology of the visual system" [34].

Ames' ideas were changed radically by his research on aniseikonia. Having invented aniseikonic lenses, he was initially baffled to find that they were not fully corrective. More generally, he was, in the words of a colleague,

struck by the fact that the perceptual anomalies produced by aniseikonia could not, in all their completeness, be explained or predicted by known physiological and optical concomitants. He turned, therefore, to what proved to be the final interest in his life, the study of the psychology of visual perception [35].

\section{THE AMES DEMONSTRATIONS}

Ames died in Hanover, New Hampshire, on 3 July 1955. During the last 15 years of his life, his most significant efforts were given to the research of a series of about 22 laboratory demonstrations, which are now commonly known as the "Ames Demonstrations in Perception". These were initially housed in the basement of the Choate House at Dartmouth. When the Dartmouth Eye Institute closed in 1949, the demonstrations were obtained by the Department of Psychology at Princeton University. Around 1961, they were transferred to a perception demonstration center at Brooklyn College [36].

All of the Ames Demonstrations are depicted and discussed in an interpretive laboratory manual which was initially published by Ames in 1955 [37]. Included in this manual are elaborate technical drawings from which the demonstrations can be rebuilt. In addition, six films have been made which feature several of the most memorable demonstrations [38].

For current purposes, there is no need

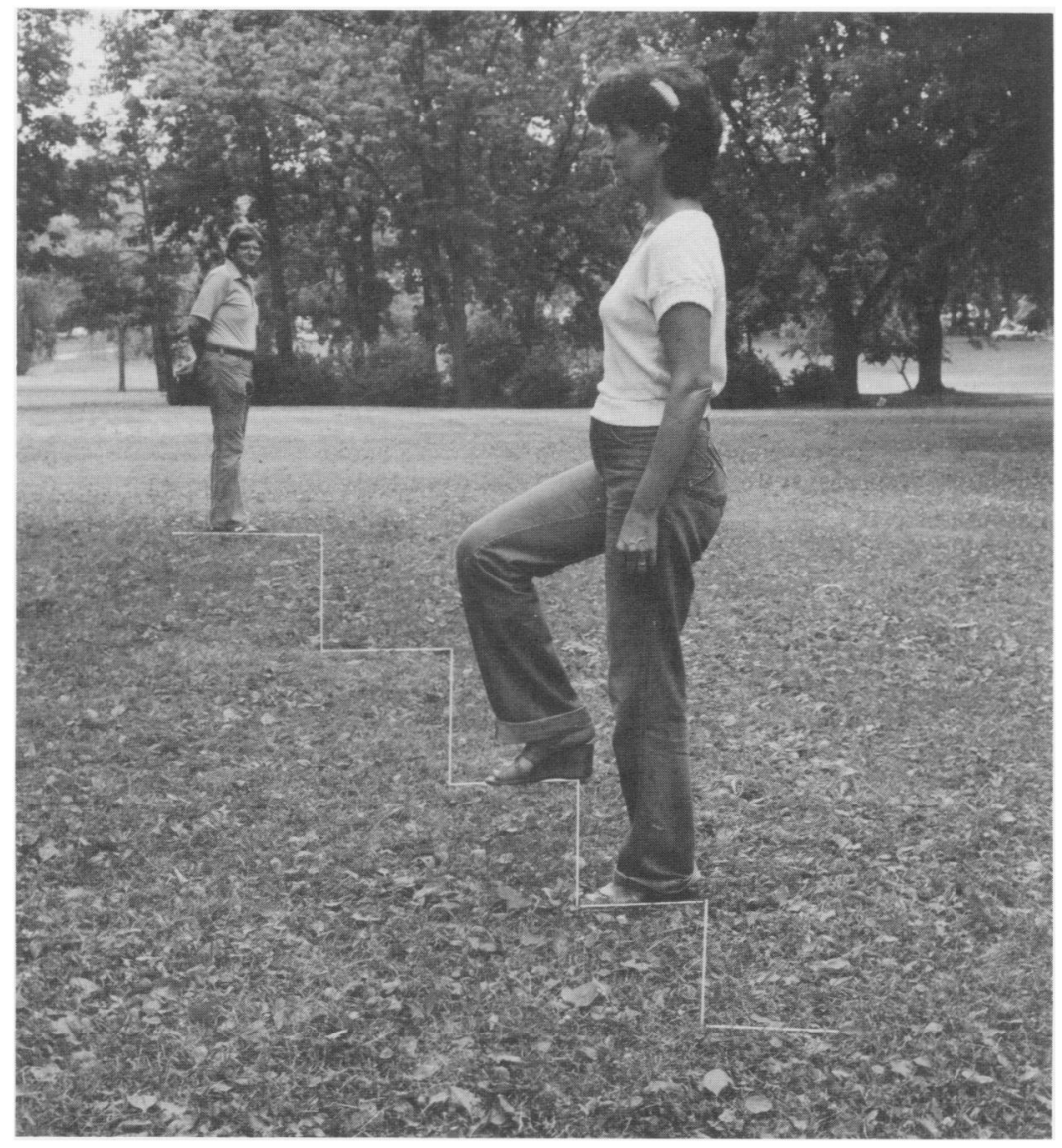

Fig. 6. The artist Amy Arntson Marein has developed a series of outdoor illusions that were inspired in part by the work of Ames. This photograph appears to show two people of differing sizes climbing a makeshift staircase. In fact, the people are the same size, and the staircase has been made by placing sticks of balsawood (of varying widths) in the ground and on the grass. (Photo: Amy Arntson Marein)

to describe in detail all of the Ames Demonstrations. Here are brief descriptions of five demonstrations:

(1) In the Overlay Demonstration (Fig. 1), one playing card (card A) appears to lie in space behind a second card (card B). The view of the first card is partially blocked by the second card. When they are observed from other positions, it is apparent that the initial perception was wrong. In fact, card B is behind card A. A section of $A$ has been cut out, making it seem that the corner was blocked.

(2) In the Chair Demonstration (Fig. 2), the viewer looks into three peepholes arranged on the side of a large wooden box. Through each peephole, an object that looks like a chair is observed. However, when the lid of the box is removed so that the objects in the box can be seen from other positions, it is revealed that only one of the objects has the physical shape of a chair. The remaining objects turn out to be assemblies of odd and nonsensical suspended shapes.

(3) In the Rotating Trapezoid Demonstration (Fig. 3), a cut-out of a trapezoid has been painted to appear to be a rectangular window in perspective. It is attached to a motorized shaft which rotates at a speed of 2 revolutions per minute. While staring at this moving shape, the viewer is easily led to conclude that the window is not a rotating trapezoid. Rather, it looks like a rectangular window that is swaying back and forth.

(4) In the Architect's Room Demonstration, the viewer sees into what appears to be a square room with a set of four windows on each of the walls. However, when viewed from another position, it is apparent that the room is not square. It is long and narrow, and there are only two windows on the far wall, not four.

(5) In the Distorted Room Demonstration (Fig. 4), the viewer sees a room that looks rectangular. When objects and people are placed in this room, they seem dramatically altered in size. However, when viewed from any point other than through the peephole, it is apparent that this room is extraordinarily crooked. The right wall, for example, is only half the height of the opposite wall, and the wall at the far end is a trapezoid, not a rectangle. 


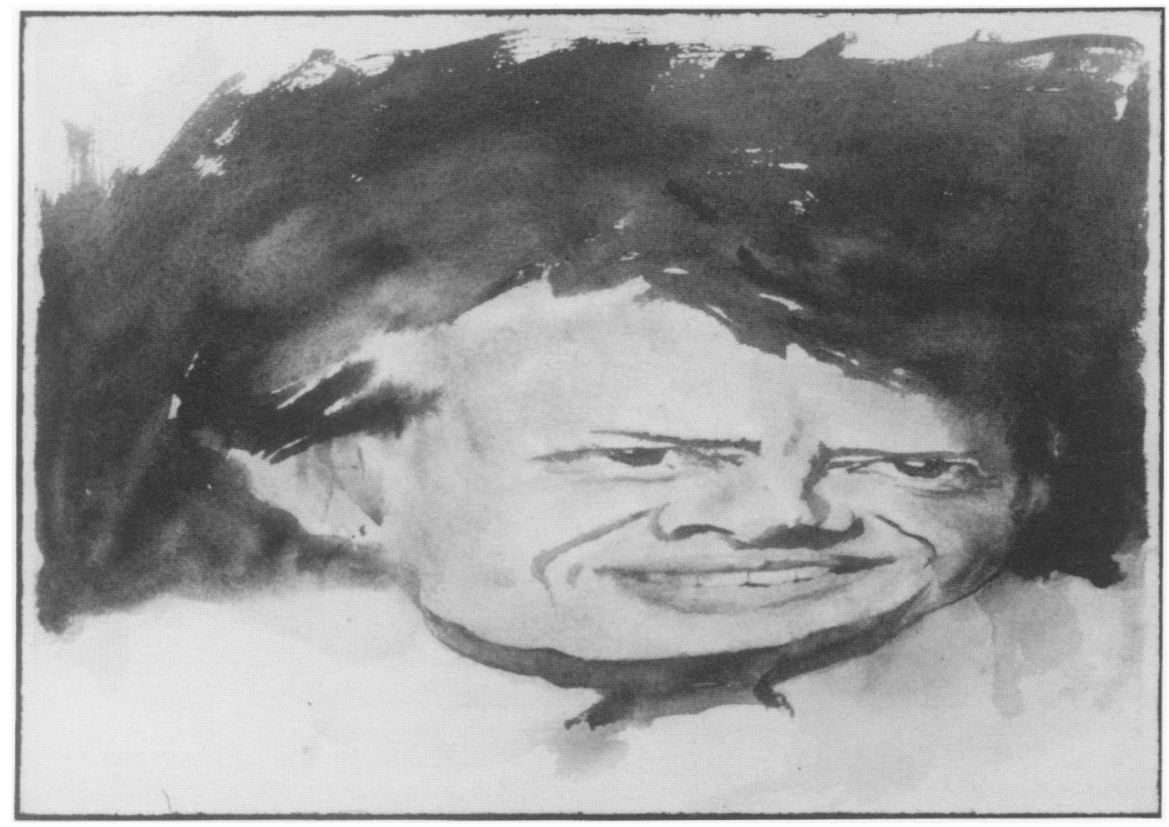

Fig. 7. Katherine Dyble Thompson, anamorphic watercolor portrait of former U.S. President Jimmy Carter, 1977.

\section{AMES AND ANAMORPHOSIS}

Almost all of the Ames Demonstrations are examples of anamorphosis, a kind of distortion that artists have used since it was invented by Leonardo da Vinci about 1485 [39].

Perhaps the most famous example is found in a painting by Hans Holbein, The Ambassadors, dated 1533. In the foreground of that work is the elongated shape of a skull, stretched out in such an extreme way that it is barely recognizable. However, if the painting is hung above a doorway (as the artist may have intended) and viewed from an oblique position below, the skull is clearly discernible [40].

When Leonardo discovered anamorphosis (there are two anamorphic drawings in his notebooks), he called it 'accidental perspective' because it was largely the consequence of a misunderstanding or an intentional misuse of linear perspective. In linear perspective, the work is designed to be viewed from the front. In anamorphosis, the work is designed to be viewed from an oblique angle (Fig. 5).

Linear perspective presupposes a perpendicular picture plane, while anamorphosis presents us with an oblique plane in the guise of being perpendicular. Most of the Ames Demonstrations are examples of anamorphosis in that they consist of oblique planes (e.g. the rear wall of the Distorted Room, the Rotating Trapezoid, the side walls of the Architect's Room, various sections of the Chair Demonstration) which are mistakenly seen as perpendicular.

During Ames' lifetime, surprisingly little was written about the historical significance of anamorphic art. The first major book on the subject was published in 1969 [41]. Ames may not have been aware of historical examples of anamorphosis, most of which were little known. In his writings, there is no mention of anamorphosis. Indeed, even since his death, only a couple of writers have made an explicit connection between anamorphic art and the Ames Demonstrations [42].

On the other hand, there are a number of artworks produced in the past several decades that are examples of anamorphosis and that appear to be spin-offs from Ames, naively or with the intention of that. Some of these artworks (e.g. those by Markus Raetz, Jan Beutener and Jan Dibbets) have been reproduced in books on anamorphic art [43]. There are more subtle allusions to Ames in the works of John Pfahl, Michael Bishop, Robert Cumming and Robert Irwin [44]. In 1973, some of the Ames Demonstrations were reconstructed by John Volker and myself as part of a children's exhibit (see Fig. 4). In 1981, Amy Arntson Marein (who was at that time my student) experimented with modifications of Ames-like anamorphoses at the University of WisconsinMilwaukee (Fig. 6). Other students have produced anamorphic paintings and drawings (Fig. 7).

\section{ASSESSMENTS OF AMES}

It has sometimes been stated that the first Ames Demonstrations were built around 1938 . This is probably inaccurate.
As early as 1930, when Ames was introduced to the American social philosopher Lewis Mumford, he demonstrated for Mumford

some of his ingenious experiments that showed-conclusively, I believe-that pure sensations do not register automatically, by a reaction similar to the chemical changes in a photosensitive film; that every sensation is a perception that draws on the past experience and the present purposes of the organism [45].

In April of 1934, while teaching at Harvard, the British philosopher Alfred North Whitehead referred to Ames in conversation as

\begin{abstract}
a man whose discoveries in the field of psychology and optics have made him eminent in Europe and America. If you were to talk with him you would at once discover that you were speaking with a poet and a mystic [46]
\end{abstract}

On another occasion, Whitehead described Ames as "an authentic genius" [47].

According to Fritz Heider, a gestalt psychologist, some of the demonstrations had been constructed by 1936 , when members of the American Psychological Association met at Dartmouth. As Heider recalled, Ames was hopeful that he could get some of them to his laboratory

but they only shook their heads and said: "Very amusing, but we are sorry What you have there are optical illusions that have been well known to psychology for a long time. All these problems were solved thirty years ago" [48]

Heider was in contact with Ames during the summer of 1945 , when he and his colleague Kurt Lewin visited the Dartmouth Eye Institute. By Heider's account, it was he who first showed Ames the Chair Demonstration, although in his version he simply used cubes.

Ames was greatly pleased with this suggestion. When I visited him again in the fall, he had constructed a very nice setup to demonstrate the effect that I described, but with one difference that he had introduced: he used a chair instead of a cube for the model of the object that would appear at a distance [49]

At nearly the same time, Lewis Mumford returned to Hanover, where he remained for several years. He now became a frequent acquaintance of Ames, who was in desperate need at the time of "someone who would put his observa- 
tions and theories into viable literary form: so more than once he tentatively suggested that I might join him in this task".

Mumford responded by initiating a dialogue, but found that

when I tentatively broached some of my doubts to Ames, he shrank back into his private shell: the collaboration he begged for did not in fact allow for any criticism and rectification. Though I asked for the privilege more than once, he never invited me to go through his series of experiments a second time [50].

In the summer of 1946, the demonstrations were observed by Hadley Cantril, a psychologist, and Earl C. Kelley, a teaching specialist, who were proponents of what has been called 'transactional psychology' [51]. Through the efforts of Kelley and the American philosopher William H. Kilpatrick, Ames was persuaded to transport some of the demonstrations to New York in November 1946, where they were set up to be shown to John Dewey, the philosopher and educator, who was 87 years old [52]. Thereafter, Ames and Dewey exchanged letters until shortly after Dewey's 91st birthday. In his last letter to Ames, Dewey wrote: "I think your work is by far the most important work done in the psychological-philosophical field during this century-I am tempted to say the only real important work" [53].

Later, in the early 1950s, Ames was also visited by two Harvard psychologists, Jerome Bruner and Leo Postman, founders of the 'New Look' in cognitive psychology. As Ames guided them through the demonstrations, they were not as buoyant as Dewey had been. Bruner suggested to Ames that

it would be interesting to study the 'buildup' of his demonstration illusions by the use of tachistoscopic flashes. He did not think much of that. It was demonstration he was after, not experimental manipulation. And demonstration of a kind that, I think, speaks more to the artist's wonder than to the scientist's [54].

It was of interest to find out that Jerome Bruner's second wife is a niece of Adelbert Ames, Jr. Nonetheless, this is his parting assessment of Ames: "In the end, he had little impact on psychology or philosophy, but he continues to fascinate artists" [55].

Acknowledgments-The author would like to acknowledge the kind cooperation of Adelbert Ames III, who responded to questions regarding his father in letters dated 19 August 1981,
13 June 1986, and 23 November 1986. This research was partly supported by a Faculty Research Grant, provided by the Graduate School of the University of WisconsinMilwaukee, 1985.

\section{REFERENCES AND NOTES}

1. The given name of Adelbert Ames, Jr., is mistakenly listed as Adalbert in the following sources: Rudolf Arnheim, Art and Visual Perception (Berkeley: University of California Press, 1974); Morse Peckham, Man's Rage for Chaos (New York: Schocken Books, 1967); and Leonard Zusne, Names in the History of Psychology (Washington, D.C.: Hemisphere Publishing, 1975). Among friends and family, he was known as Del Ames. 2. See William H. Ittelson, The Ames Demonstrations in Perception (New York: Hafner Publishing, 1968).

3. The Ames family is discussed in the following volumes: Blanche Ames Ames, Adelbert Ames 1835-1933 (New York: Argosy-Antiquarian Ltd., 1964); Blanche Butler Ames, Chronicles from the 19th Century: Family Letters of Blanche Butler and Adelbert Ames (Privately published, 1957); Winthrop Ames, The Ames Family of Easton, Massachusetts (Privately published, 1938); and Pauline Ames Plimpton, ed., Oakes Ames: Jottings of a Harvard Botanist 1874-1950 (Cambridge, MA: Botanical Museum of Harvard University, 1979). Among botanists, Oakes Ames is widely known for his studies of orchids. George Plimpton, author of The Paper Lion and other books, is the grandson of Blanche Ames Ames, sister of Adelbert Ames, Jr.

4. The flour mill of Captain Jesse Ames still stands in downtown Northfield, not far from the First National Bank, site of the last Jesse James bank robbery in 1876. At the moment of that robbery, Jesse Ames and his two sons, Adelbert and John, were walking toward the mill, having just attended a board meeting at the bank. Years later, Cole Younger, an outlaw who survived the raid, claimed that the James gang had chosen the Northfield bank because they believed that Generals Ames and Butler had made large deposits there. This and related information was obtained from the Northfield Historical Society, Box 372, Division Street, Northfield, MN 55057.

5. Detailed information regarding the life of General Adelbert Ames can be found in Blanche Ames Ames [3] and Blanche Butler Ames [3].

6. See entry regarding Adelbert Ames, Jr., in National Cyclopaedia of American Biography (New York: J.T. White, 1892-).

7. Plimpton [3] p. 282.

8. See Plimpton [3], and entries regarding Oakes Ames and Blanche Ames in National Cyclopaedia of American Biography [6].

9. Jerome Bruner, In Search of Mind: Essays in Autobiography (New York: Harper and Row, 1983) p. 89.

10. Adelbert Ames, Jr., "Systems of Color Standards", Journal of the Optical Society of America 5, 160-170 (1921), p. 168.

11. Ames [10]. Plimpton [3] p. 282 reproduces a photograph of Adelbert and Blanche, seated on lawn chairs, surrounded by color swatches.

12. Faber Birren, Color, A Survey in Words and Pictures (New Hyde Park, NY: University Books, 1963) pp. 148-149.

13. Ames [10] p. 168.

14. See Oakes Ames' diary entry for 15 February 1912, quoted in Plimpton [3]p. 281: "Blanche is busy with her still life picture. In the forenoon she mixed the colors, after carefully matching with the color charts, and in the afternoon she began to paint. I believe she has hit upon a really scientific method which will lead to startling results." In the same book, a letter from Oakes Ames to Blanche, dated 25 July 1916, indicates that she was still using the color matching system (pp. 291-292).

15. Ref. [6]

16. Ref. [6].

17. Letter to author from Adelbert Ames III, dated 19 August 1981.

18. Ref. [6].

19. See Adelbert Ames, Jr., C.A. Proctor and Blanche Ames, "Vision and the Technique of Art", Daedalus (Proceedings of the American Academy of Arts and Sciences) 58, 3-47 (1923)

20. Ref. [19].

21. Ref. [19], p. 39.

22. Ref. [19], pp. 34-36.

23. Ref. [19]. See also Adelbert Ames, Jr., "Depth in Pictorial Art", Art Bulletin 8, 5-24 (1925).

24. See Roy R. Behrens, Illustration as an Art (Englewood Cliffs, NJ: Prentice-Hall, 1986) pp. 137-139.

25. See William H. Ittelson, Visual Space Perception (New York: Springer Publishing, 1960), chapter 8 .

26. Adelbert Ames, Jr., "Aniseikonia-A Factor in the Functioning of Vision", American Journal of Ophthalmology 18, 1014-1020 (1935).

27. See S. Howard Bartley, Perception in Everyday Life (New York: Harper and Row, 1972) pp. 238-242. I am uncertain of the current status of aniseikonia in the field of ophthalmology. It is conceivable that Ames' diagnosis is no longer regarded as useful or true.

28. Ref. [6]

29. A list of his technical papers is found in "Adelbert Ames, Jr., Edgar D. Tillyer Medalist for 1955", Journal of the Optical Society of America 45, 333-337 (1955).

30. See Ref. [6] for a list of Ames' patents.

31. Ref. [6].

32. Fritz Heider, The Life of a Psychologist: An Autobiography (Lawrence: University Press of Kansas, 1983) pp. 139-140.

33. Ref. [6]

34. Journal of the Optical Society of America [29] p. 333.

35. Ittelson [2] p. iv.

36. See Foreword by Hadley Cantril in Franklin P. Kilpatrick, ed., Explorations in Transactional Psychology (New York: New York University Press, 1961) p. v. As of this writing, I have not determined the current location of the original demonstrations. I would be delighted to hear from anyone who knows if they are still extant.

37. Ames' An Interpretive Manual has been republished in Ittelson [2] pp. 1-130.

38. The following $16 \mathrm{~mm}$ films contain footage of one or more of the Ames Demonstrations: Demonstrations in Per- 
ception, 1951 (ISBN 0-699-07225-5); Experience as Give and Take, 1958 (ISBN 0-699-09439-9); Seeing Isn't Believing, 1952 (ISBN 0-699-26110-4); Sense Perception, Part Two: The Limitations of the Senses, 1960 (ISBN 0-699-26191-0); Visual Perception, 1959 (ISBN 0-699-31154-3); and Visual Perception, 1954 (ISBN 0-69931153-5). To determine the location of rentable copies of these films, consult the Educational Film Locator (New York: R.R. Bowker, 1978).

39. Jurgis Baltrusaitis, Anamorphic Art, W.J. Strachan, trans. (New York: Harry N. Abrams, 1977) p. 33. The original French edition was entitled Anamorphoses ou magie artificielle des effets merveilleux (Paris: Olivier Perrin Éditeur, 1969).

40. Baltrusaitis [39], pp. 91-114.

41. Baltrusaitis [39].

42. See Behrens [24] pp. 119-126; and E.H. Gombrich, Art and Illusion (New York: Pantheon Books, 1961) pp. 248ff.

43. See Fred Leeman, Michael Schuyt and Joost Elffers, Hidden Images (New York: Harry N. Abrams, 1976); and Fred Leeman et al., Anamorphoses: Games of Perception and Illusion in Art (New York: Abrams, 1976).

44. See Sally Eauclaire, The New Color Photography (New York: Abbeville Press, 1981) pp. 97-106; Patricia G. Foschi, "Robert Cumming's Eccentric Illusions", Art Forum 13, 38-39 (1975); and Lawrence Weschler, Seeing Is Forgetting the Name of the Thing One Sees: A Life of Contemporary Artist Robert Irwin (Berkeley: University of California Press, 1982).

45. Lewis Mumford, Sketches from Life (New York: Dial Press, 1982) pp. 323324. In reading this statement by Mumford, it should not be forgotten that the Ames illusions do indeed register on photographic film.

46. Lucien Price, ed., Dialogues of Alfred North Whitehead (New York: New American Library, 1956) p. 27.

47. Hadley Cantril, ed., The Morning Notes of Adelbert Ames, Jr. (New Brunswick, NJ: Rutgers University Press, 1960) p. v.
48. Heider [32] p. 140.

49. Heider [32], pp. 140-141. Prior to constructing the Chair Demonstration, Ames also constructed a Cube Demonstration, drawings of which can be found in Walter Gropius, "Design Topics", Magazine of Art 40, 299-304 (1947); and Earl C. Kelley, Education for What Is Real (New York: Harper and Brothers, 1947) pp. 26-27. In a somewhat similar way, the Architect's Room Demonstration may have originated about 1946, when (according to Ames' son) the architect Wallace K. Harrison, who was designing the interior of the United Nations Secretariat Building, spoke to Ames about the possibility of 'camouflaging' the oblongated appearance of some of the conference rooms.

50. Mumford [45] p. 324.

51. See Kilpatrick [36] and Kelley [49]. Cantril was Professor of Psychology at Princeton, Kelley was Professor of Secondary Education at Wayne State University

52. Cantril [47] p. 171.

53. Cantril [47] pp. 230-231. For Dewey's doubts regarding Ames, see Sidney Ratner and Jules Altman, eds., John Dewey and Arthur F. Bentley: A Philosophical Correspondence, 1932-1951 (New Brunswick, NJ: Rutgers University Press, 1964).

54. Bruner [9] p. 89. If Ames was reluctant to use a tachistoscope, one of his enthusiasts, Hoyt Sherman, the late Professor of Art at Ohio State University, made extensive use of it. Sherman was the author of Drawing by Seeing (New York: Hinds, Hayden and Eldredge, 1947), a detailed account of his tachistoscopic method of teaching drawing in the dark. After spending several weeks with Ames in Hanover, Sherman returned to Ohio, where he developed a visual demonstration center which duplicated many of the Ames Demonstrations. "On meeting Adelbert Ames," Sherman recalled, "I sensed immediately that he was a simple but profound man." See the interview with Sherman in David W. Ecker and Stanley S. Madeja, Pioneers in Perception: A Study in Aesthetic Perception (St. Louis, MO: CEMREL, Inc., 1979).

55. Bruner [9] p. 90. Not everyone would agree with Bruner's assessment of the life and work of Ames. Peckham [1], for one, writes appreciatively of the work both of Ames and of Bruner (pp. $208 \mathrm{ff}$.). In addition, it was of interest to learn that Peckham's father, Dr. Ray Morse Peckham, "lived in Connecticut in the 1920 s and practiced optometry. $\mathrm{He}$ became friendly with Adalbert [sic] Ames, then at Dartmouth, and worked with him on some of his experiments" (pp. 214215 ). As a final note, it may be of value to point out three other examples of Ames' influence on American culture: First, the Northfield Historical Society [4] has provided an article by Bob Warn (an apprentice to Frank Lloyd Wright), published in the Golden Nugget on 3 May 1972 and 17 May 1972, in which he remembers Wright's enthusiasm for Ames' research (they had met at Princeton University in 1947), especially while Wright was involved with the design of the Guggenheim Museum. Second, the comedian Ernie Kovacs used a modified Ames Room in a 30 minute television program entitled "Ernie" (circa 1952). Third, Ames has had an impact on certain American roadside tourist attractions, which usually promote themselves as 'mystery buildings' or 'mystery spots' in which people seem to lean and balls appear to roll uphill. There is a photograph of one of these rooms (located in Gold Hill, Oregon) in Leonard Zusne and Warren H. Jones, Anomalistic Psychology: A Study of Extraordinary Phenomena of Behavior and Experience (Hillsdale, NJ: Lawrence Erlbaum, 1982). I am eager to receive any additional information (anecdotes, sources, citations) regarding Ames, the Ames Demonstrations or related phenomena. 